Holocene Population History in the Pacific Region as a Model for Worldwide Food Producer Dispersals

Author(s): Peter Bellwood

Reviewed work(s):

Source: Current Anthropology, Vol. 52, No. S4, The Origins of Agriculture: New Data, New Ideas (October 2011), pp. S363-S378

Published by: The University of Chicago Press on behalf of Wenner-Gren Foundation for Anthropological Research

Stable URL: http://www.jstor.org/stable/10.1086/658181

Accessed: $0 7 \longdiv { / 1 1 / 2 0 1 1 2 0 : 1 8 }$

Your use of the JSTOR archive indicates your acceptance of the Terms \& Conditions of Use, available at http://www.jstor.org/page/info/about/policies/terms.jsp

JSTOR is a not-for-profit service that helps scholars, researchers, and students discover, use, and build upon a wide range of content in a trusted digital archive. We use information technology and tools to increase productivity and facilitate new forms of scholarship. For more information about JSTOR, please contact support@jstor.org. 


\title{
Holocene Population History in the Pacific Region as a Model for Worldwide Food Producer Dispersals
}

\author{
by Peter Bellwood
}

\begin{abstract}
Pacific prehistory (excluding Australia) since $3000 \mathrm{BC}$ reflects the impacts of two source regions for food production: China from the Yangzi southward (including Taiwan) and the western Pacific (especially the New Guinea Highlands). The linguistic (Austronesian, Trans-New Guinea), bioanthropological/human genetic, and Neolithic archaeological records each carry signals of expansion from these two source regions. A combined consideration of the multiregional results within all three disciplines (archaeology, linguistics, and biology) offers a historical perspective that will never be obtained from one discipline or one region alone. The fundamental process of human behavior involved in such expansion-population dispersal linked to increases in human population size-is significant for explaining the early spreads of food production and language families in many parts of the world. This article is concerned mainly with the archaeological record for the expansion of early food producers, Austronesian languages, and Neolithic technologies through Taiwan into the northern Philippines as an early stage in what was to become the greatest dispersal of an ethnolinguistic population in world history before $\mathrm{AD} 1500$.
\end{abstract}

\section{Introduction}

The organizers of the Wenner-Gren conference "The Origins of Agriculture: New Data, New Ideas" asked me to examine the dispersal of agricultural systems in the Pacific and the relationships among language, culture, and farming in the area and also to discuss to what extent I think this model provides for a more general understanding of the dispersal of languages and farming in other parts of the world. At the outset, I wish to make my fundamental perspective clear. The dispersal of the Austronesian language family and its speakers commenced after $4000 \mathrm{BC}^{1}$ among increasing populations of Neolithic food producers in southern China and Taiwan, in a cultural situation of increasing population density, advancing technology (including boat construction and carpentry), and increasing dependence on agriculture and animal domestication, also a portable food production repertoire that allowed long-distance dispersal to take place. Food production and the remarkable lithic and lignic technology behind it thus underpinned the expansion, and without them it is unlikely

Peter Bellwood is Professor of Archaeology in the School of Archaeology and Anthropology, Australian National University (Canberra, Australian Capital Territory 0200, Australia [peter .bellwood@anu.edu.au]). This paper was submitted 13 XI 09, accepted 1 XI 10, and electronically published $13 \mathrm{~V} 11$. that populations would have migrated when they did into the remote reaches of Oceania. No stage in Austronesian dispersal involved populations who permanently abandoned all commitment to food production unless forced to do so by environmental circumstances, no matter how significant the contributions of fishing, bird and sea-mammal hunting, and wild-plant consumption were in initial colonizing situations of natural plenty. No claim is made that farming drove the expansion via overpopulation or a desperate search for new territory, but the systematic development of food production stands forward as the fundamental cultural basis for the expansion.

My topic thus focuses on dispersals of agriculture, languages, and attached human populations, and not specifically on the ultimate origins of food production systems in China or New Guinea or gradients in their development through stages such as predomestication cultivation or low-level food production. We start with populations in southern China and Taiwan before $3000 \mathrm{BC}$ who manifested already an identifiable level of dependence on food production.

Initially, I offer several introductory observations presented in more detail elsewhere (Bellwood 2001, 2005, 2008, 2009a, 2009b; Bellwood and Oxenham 2008). (a) Spreads of food production and human migration in general are phenomena

1. All dates are expressed as $\mathrm{BC} / \mathrm{AD}$ and based on calibrated $\mathrm{C} 14$ determinations. 
that have always involved demographic growth-declining populations cannot create successful colonists. Birth rates must exceed death rates over the long term. (b) Archaeology and comparative linguistics attest to coherent movements of food-producing populations from several large homeland regions in different parts of the world. (c) Food production in general spread with existing food producers even when previous hunter-gatherer populations existed, the more so as dependence on morphologically domesticated plants and animals increased within the food producers' diet. $(d)$ Migration and interaction have played different roles in creating cultural and biological patterns within humanity (Bellwood 1996; see Hunley et al. 2008 for western Oceania). Migration, as a sporadic rather than continuous occurrence on any large scale, has laid down successive foundations of biological phylogeny and cultural/linguistic genealogy. Interaction has continually and productively modified these foundations, normally reorganizing rather than suddenly replacing previous patterns. (e) In general, major movements of languages in prehistoric societies occurred with major movements of native speakers, not through language shift or the expansion of "trade languages." Ostler (2005) and Ross (2008) have discussed these matters in detail, the latter for Austronesian, and those who believe in trade languages as the source of any extensive ancient language landscape should consider Melanesia-home for some of the most famous exchange systems in world ethnography yet also one of the most diverse linguistic regions in the world in terms of its high number of mutually unintelligible precolonial languages. Exchange in Melanesia did not homogenize languages. Indeed, it probably had the opposite effect through its role in underpinning group identity. Communication relied on multilingualism, not language shift. This is one reason why the recent linguistic arguments by Donohue and Denham (2010) for the spread of Austronesian languages by elite dominance, as lexical replacements within existing non-Austronesian languages, are unconvincing. $(f)$ Comparative linguistics is also of absolutely fundamental importance in offering hypotheses about language-family homelands, directions, and relative chronologies of subgroup dispersal as well as protolanguage reconstructions of meanings relevant for archaeological inference. Linguistic reconstructions can be deeply meaningful for historical understanding given the importance of language as the most significant vehicle of human expression and interaction.

My operational model for early agriculturalist dispersal is that of "demic diffusion" involving a food producer "wave of advance" extending or leapfrogging, as the case may be, and mixing with forager populations as proposed originally for Europe by Ammerman and Cavalli-Sforza (1973). This is a logical mechanism for population expansion, involving continuous population growth in frontier regions, fissioning, and intermarriage with other communities. It is not necessarily a mechanism for population replacement. The "early farming dispersal” hypothesis (Bellwood 2005, 2009a, 2009b; see also Renfrew 2002) does not demand extermination of foragers by early farmers; indeed, the latter would probably have welcomed new members from foraging communities before the development of sufficient population density to promote resource competition. Well-studied farming dispersals in Europe, the Andes (Heggerty and Beresford-Jones 2010), South Asia, and China required more than 3,000 years for completion, and homeland genetic configurations could not possibly have spread intact and hermetically sealed through such long time spans.

The validity of the demic diffusion model is strengthened by analyses of early food-producing cemetery populations that indicate marked increases in birth rate following the regional appearances of agriculture and animal husbandry. These increases occurred before the later increases in mortality that resulted from the crowded and insanitary lifestyles associated with increasingly sedentary life (Bocquet-Appel 2011). Increasing populations must either seek fresh land or intensify production in order to survive, and the former option would often have been inviting in situations surrounded by lowerdensity forager populations. The historical validity of such a model is also revealed for us by a small number of ethnohistorical small-scale and kinship-based tribal populations who managed to avoid the main hazards of the colonial era. One such group were the Iban of Sarawak (Borneo), swidden rice farmers with long fallow land requirements who were colonizing along rivers starting perhaps in the late eighteenth century and continuing into the early decades of the twentieth century (Freeman 1970). The movements spanned an alreadypopulated territory stretching more than $850 \mathrm{~km}$ from western Kalimantan through Sarawak to Brunei Bay. According to Freeman,

The main incentive behind the remarkable migrations of the Iban has been a desire to exploit new tracts of primeval forest, and the tendency has been for communities to abandon their land as soon as a few lucrative harvests have been reaped, and move on to fresh precincts. (Freeman 1970:76)

The Iban expansion, with its consequent assimilation of intervening populations, can be compared with that of the ethnographic Yanomami of the upper Orinoco as described by Chagnon (1992) and the Nuer of Sudan as described by Kelly (1985). All represent demic spreads of food producers into terrain inhabited either by foragers or by other less aggressive food producers. Interestingly, recent genetic research in Bali (Lansing et al. 2008) has revealed that modern subak irrigation associations have low genetic diversity and so probably formed by internal demographic growth through fissioning from founder populations into adjacent drainage systems, rather than by state-enforced population movement. Although not directly related to Neolithic issues, there is an interesting model here for the gradual spread of earlier farming populations through demographic growth. 


\section{Agricultural Origins in East Asia and the Pacific}

What is the central question? I suppose it has to be why at the beginning of the colonial era (AD 1500 for argument's sake) were the majority of populations in Southeast Asia and Oceania subsisting from the proceeds of food production? Continuations of foraging, hunting, and fishing from the wild are irrelevant for the question posed because they have always existed and always will, global warming permitting. Likewise, all ethnographically recorded foragers manage resources in one way or another. Predomestication cultivation and lowlevel food production (Smith 2001, 2011) are useful concepts for the beginnings of food production, and the latter will always exist among ecologically marginal communities, but the focus here is on the conscious production of food from combinations of wild and domesticated species in nonmarginal environments sufficiently productive to support outward population expansion.

Within the Asia-Pacific region, the inceptions of food production occurred independently in the New Guinea Highlands and central China (the Yangzi and Yellow river basins). In both regions, some populations were reasonably dependent on food production by 4000 BC (Cohen 2011; Denham 2011; Fuller, Harvey, and Qin 2007; Zhao 2011). China witnessed the development of cereal (rice, foxtail, and common millet), legume (soybean), and pig production. Whether the Yellow and Yangzi river basins formed one or two "centers" is not relevant for present purposes-I suspect only one on the evidence of cultural connections, but animal domestication appeared slightly later in the south than in the north (Yuan, Flad, and Luo 2008). The New Guinea Highlands, a unique high-altitude and equatorial-cordilleran environment without geomorphic parallel anywhere in the volcanic arcs of Island Southeast Asia, witnessed the development of tuber and fruit cultivation without cereals or domestic animals.

Chinese material culture was quintessentially "Neolithic," with pottery, sawn and ground stone, weaving, advanced carpentry, and boats and paddles, whereas New Guinea Highland material culture was less modified from its Pleistocene lithic and aceramic roots, except for the addition of fully polished stone axes during the Holocene. New Guinea Highland archaeology reveals no signs of direct contact with contemporary Neolithic societies in Island Southeast Asia, although the situation was different with respect to the islands of Melanesia and lowland New Guinea. Movements of useful plants such as sugarcane, bananas, and taro from New Guinea into Indonesia in the mid-Holocene are perfectly possible, as claimed by Donohue and Denham (2010), but are so far undemonstrated. So, too, are pre-Neolithic movements the other way, from Indonesia into New Guinea.

Following the development of food production in central China, outward migrations of farming populations with their genes, material cultures, and languages occurred widely between 3000 and $1000 \mathrm{BC}$, when populations moved via south- ern China to reach ultimately as far as the Ganges Basin, Sumatra, and Samoa. These movements sometimes involved migration into uninhabited terrain, but more common were processes of demic diffusion into regions already occupied by indigenous populations. However, the New Guinea Highland populations restricted their biological and cultural influences to the western Pacific, and while some degree of migration might have occurred, particularly from Trans-New Guinea genetic and linguistic perspectives (Mona et al. 2007; Pawley 2007), it was evidently not dramatic. This situation reflects the differing capacities of the food production systems in China and New Guinea to support internal population growth via increased birth rates. Cereals, legumes, and pigs fueled expansion from China, particularly during the period of highdensity population represented by the Qujialing, Liangzhu, and so-called Longshan cultures of the Yangzi and Yellow river basins (third millennium BC; Jing and Campbell 2009; Zhang and Hung 2008, 2010). Without cereals and domesticated animals (pigs and dogs probably arrived less than 3,000 years ago on the New Guinea mainland), the early New Guinea systems of food production were less expansive.

In terms of agricultural dispersals and human prehistory in general, Island Southeast Asia and Oceania have had different historical trajectories. East of the Solomons, in the scattered archipelagos of "Remote Oceania," human settlement has occurred only within the past 3,100 years (fig. 1). Nowhere within Remote Oceania is there evidence to suggest complete population replacement-whether genetic, linguistic, or cultural-except to a minor degree in cases such as those of the Polynesian outliers. All scholars agree that the first settlers in these islands were the direct ancestors of the populations there today, allowing for some obvious situations of later interisland migration, contact, and intermarriage (e.g., Addison and Matisoo-Smith 2010). All of these populations, without exception, speak Malayo-Polynesian languages, and all practiced noncereal food production focused on fruit/nut and tuber cultivation in one form or another at European contact, with the exception of the southern Maoris of New Zealand, who lived beyond the growing-season limits of the sweet potato, their only significant cultivated plant.

The area termed "Near Oceania" (New Guinea and western Island Melanesia), together with the much vaster extent of Island Southeast Asia to the west, is rather more complex. Modern humans presumably first reached these islands within the past $50 \mathrm{kyr}$, and their descendants in New Guinea and Melanesia were also mainly food producers at European contact. But it is in the region west of New Guinea that the contentious debates occur. Today, no one suggests that the islands of Remote Oceania underwent totally independent transitions to agriculture, but most accept that the island of New Guinea, particularly its cordilleran central highlands, supported indigenous systems of fruit and tuber food production early in the Holocene (Denham 2011). The issues involve the Southeast Asian islands-Taiwan, the Philippines, Indonesia, and East Malaysia (northern Borneo). These is- 


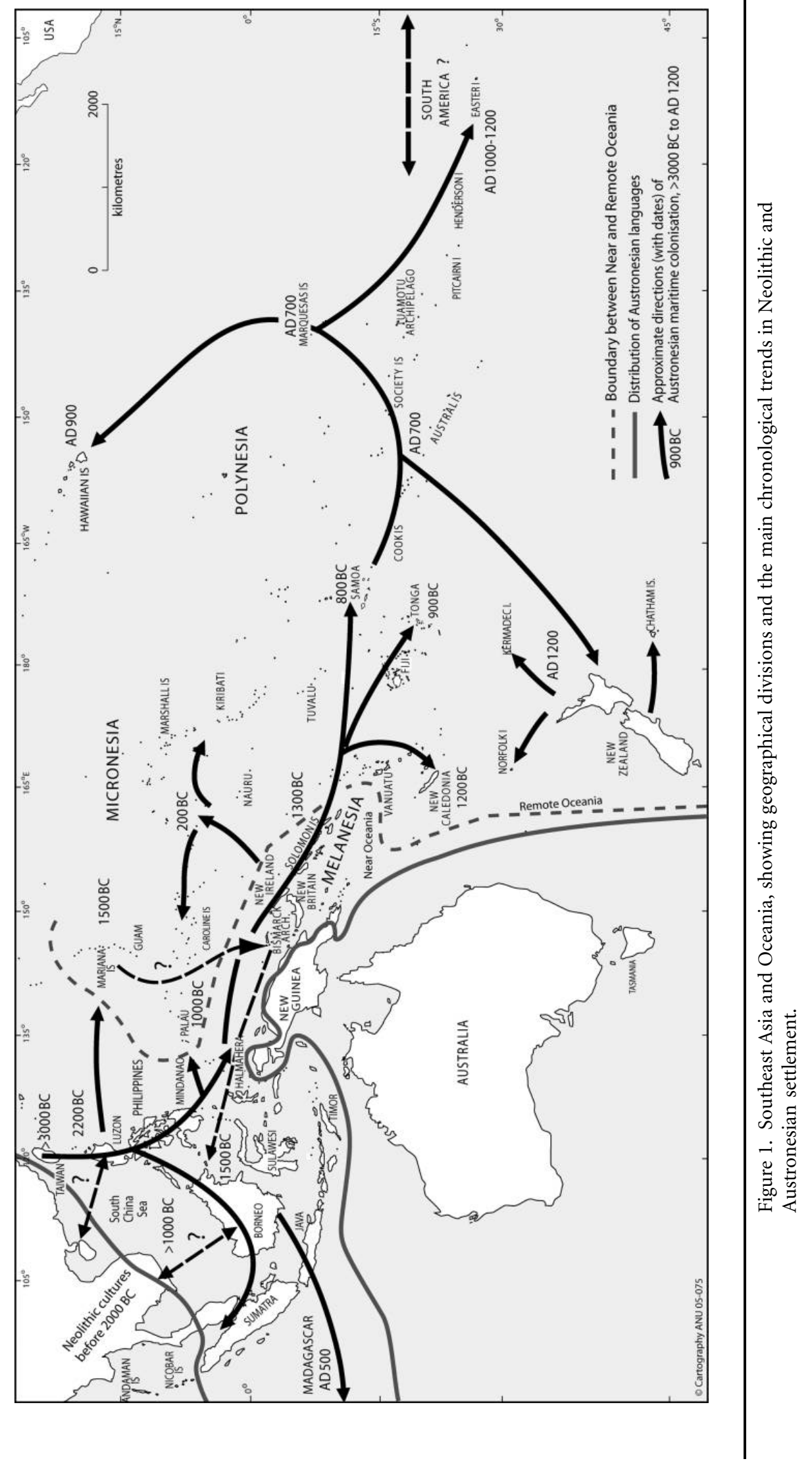


lands, except for a few immediately west of New Guinea (Timor, Halmahera, Alor, Pantar), are occupied entirely by speakers of Austronesian languages who are biologically clinal, with a dramatic and steep change from Asian to Melanesian genetic ancestry within a relatively narrow geographical window in the eastern Lesser Sunda islands and the Moluccas (Cox 2008; Cox et al. 2010; Mona et al. 2009).

At present, there is no archaeological evidence that Island Southeast Asia witnessed any independent development of agriculture, even at a very low level. We have yet to learn whether early Holocene foragers here were involved in moving around plants such as bananas, breadfruit, and sugarcane (but presumably not cereals), perhaps even selecting and planting some varieties. Yet even if people made such transfers, especially from New Guinea, well before the appearance of the Asian-derived ceramic Neolithic, it could be entirely irrelevant for understanding events since that time. The botanical origins of translocated plant species are not the issue under debate; rather, it is food production and human migration.

\section{The Austronesian-Speaking Peoples and Their Significance}

My aim here is to examine the data enshrined within the different disciplines that support the inference of a migration of ancestral populations speaking Austronesian languages, especially those within the major Malayo-Polynesian subgroup, as outlined in figure 1. I make no apology for beginning with the linguistic evidence because the Austronesian-speaking populations have a well-studied linguistic history and formed the most widespread ethnolinguistic group in the world before $\mathrm{AD}$ 1500. The Austronesian language family is a clearly defined taxon, and all current homeland theories for it focus on Taiwan (Donohue and Denham 2010; Ross 2008). As linguist Malcolm Ross notes,

Of the disciplines represented ... linguistics is probably the closest to unanimity about Austronesian origins. All Austronesian languages spoken outside Taiwan belong to a single subgroup, dubbed Malayo-Polynesian by Blust (1977), whilst the thirteen Austronesian languages still spoken in Taiwan belong to several primary subgroups (Blust 1999 proposes nine, on phonological grounds). The logical inference is that proto-Austronesian (PAn) was spoken in Taiwan, that it split initially into dialects, and that these dialects eventually diversified into separate languages. Speakers of just one of the dialects, proto-Malayo-Polynesian (PMP), left Taiwan and settled initially either on Lanyu (Orchid) Island, or somewhere in the Batanes Islands, or on the north coast of Luzon. It is speakers of languages descended from PMP who have settled the huge expanse of the Austronesianspeaking region beyond Taiwan. (cited in Bellwood et al., forthcoming)

Ross (2008) also comments that "the main reason why Austronesian languages cover the vast territory which they occupy
. . . is quite simply that their speakers dispersed, taking their languages with them" (165).

Comparative lexical reconstructions for PAn and its daughters PMP and proto-Oceanic (POc) indicate major changes in material culture through time and space (Blust 2009; Pawley 2002; Ross, Pawley, and Osmond 2007). For PAn itself, they reveal an economy focused on rice cultivation, with a large vocabulary for rice in many forms and stages of growth as well as a processing and cultivating vocabulary with words for millet, sugarcane, and possibly aroids. PMP added many fruits and tubers to this vocabulary as befitted its probable location in the tropical Philippines (Taiwan is mostly temperate in latitude). POc witnessed the ultimate loss of rice under equatorial climatic and day-length conditions (Paz 2002:280). Other reconstructions apply to words for pigs and dogs (but not chickens until PMP), pottery, boats and sails, fishing, and a wild placental (not marsupial) mammal fauna. The morphological and semantic integrity of these many reconstructions, as Pawley (2002:266) points out, implies continuous linguistic transmission through time, not late borrowing. In other words, Austronesians did not start as farmers, revert to foraging and lose all their farming vocabulary, and then readopt farming much later. Even the few centuries of naive faunal exploitation on Remote Oceanic islands did not reduce the food-producing vocabulary of Polynesians. Furthermore, the rakelike phylogeny of the main MP subgroups implies rapid migrational spread at least from the Philippines to as far east as western Polynesia (Gray, Drummond, and Greenhill 2009; Pawley 1999).

The recent claim by Donohue and Denham (2010) that differing geographical distributions of Malayo-Polynesian grammatical features in Island Southeast Asia imply only a spread of Austronesian vocabulary, not whole languages, hence without significant population movement, is not convincing. No recorded non-Austronesian languages survive for comparative purposes west of Halmahera and Timor, and the described grammatical variations could also be due to contactinduced change operating subsequently to the period of initial Malayo-Polynesian settlement. Furthermore, their claim does not explain why Malayo-Polynesian languages are spoken across the entirety of the Philippines and Indonesia, west of Timor and Halmahera, yet not spoken at all in most of the interior of New Guinea. Why was New Guinea different if, as Donohue and Denham claim, food production existed across the whole area in pre-Austronesian times? How could Austronesian languages possibly have spread by processes that involved almost no population movement? Naturally, preAustronesian languages once occurred in Island Southeast Asia; the disagreement concerns not their existence but their role in the formation of the modern languages of the region.

Despite the clarity of their shared ancestry in a linguistic sense, Austronesian biological origins are expectably more diverse. Not all Austronesians share a recent genetic origin, and the prehistories of some regions in eastern Indonesia and the western Pacific have involved a high degree of genetic 
indigenization and localized instances of full language shift (Mona et al. 2009). Nevertheless, while Donohue and Denham (2010) rely on somewhat outdated molecular clockbased mitochondrial DNA analyses to support their claimed refutation of any significant Austronesian population expansion, the reality from current genetic research-haploid, autosomal, and increasingly at a whole-genome level-is that Holocene population movement from mainland Asia via Taiwan into Island Southeast Asia and Oceania is very strongly supported (Cox 2008; Cox et al. 2010; Friedlaender et al. 2008; Kayser 2010; Kayser et al. 2008a, 2008b; Kimura et al. 2008; Tabbada et al. 2010). The genetics of human stomach bacterial parasites (Moodley et al. 2009) provide additional confirmation.

\section{Current Archaeological Perspectives: New Research in Taiwan and the Philippines}

Understanding of prehistory in Taiwan and the northern Philippines has recently developed very rapidly. The main breakthroughs have come with the established presence by at least 2800 BC of an agricultural (rice and foxtail millet) economy for the Dabenkeng Neolithic culture of southwestern coastal Taiwan (Tsang 2005; Tsang, Li, and Chu 2006), with the documentation of a sixfold or greater increase in site numbers during the course of the third millennium BC in eastern Taiwan (Hung 2005:126) and also with the recovery of finegrained ceramic evidence for the spread at about $2200 \mathrm{BC}$ of Neolithic material culture from Taiwan to the Batanes Islands (previously uninhabited) and northern Luzon (Bellwood and Dizon 2005, 2008; Hung 2005, 2008). This Neolithic spread carried (not necessarily all together) red-slipped pottery with specific rim forms and body shapes, pottery spindle whorls, stone bark cloth beaters, tanged or grooved stone adzes, Fengtian (eastern Taiwan) nephrite, Taiwan slate knives and projectile points, notched pebble net sinkers, domestic pigs (Sus scrofa) and dogs, and rice (presumably domesticated but a prehistoric presence of millet still remains uncertain beyond Taiwan). A large number of these items from the Batanes Islands in the northern Philippines are shown in figure 2. A precise archaeological homeland within the island of Taiwan is not yet identifiable, and it is possible that groups from different regions were involved in many individual movements, with the closest ceramic parallels so far being focused on the southeastern coastline. Fish bone data from Eluanbi in southern Taiwan and also from Batanes indicate that the canoeborne ability to catch open-sea pelagic carnivores such as dolphinfish (Coryphaena hippurus) using trolling lures with stone shanks and bone points had also developed by at least 2000 BC (Hung et al., forthcoming).

In the case of the Batanes, excavations in five caves and rock shelters with plentiful ceramic period occupation leave no doubt that humans had not previously reached these windswept islands, protected by relatively rough sea and sometimes strong ocean currents, until the Neolithic. There is absolutely no trace in caves or surface finds of prior hunter-gatherer preceramic occupation or flaked lithic tool manufacture. Luzon, to the contrary, had Paleolithic hunters and gatherers in occupation since at least 24,000 and possibly 67,000 years ago, so the first Neolithic arrivals must have interacted with these groups, as Mijares has shown for the Peñablanca Caves near Tuguegarao (Mijares 2006; Mijares et al. 2010).

\section{The Spread of Neolithic Pottery from Taiwan into the Philippines and Indonesia}

Newly excavated ceramic data establish the development of a tradition of red-slipped plain ware pottery manufacture in southern and eastern Taiwan, emergent by at least 2200 BC from a prior "Middle Neolithic" tradition with both cord marking and red slip (Bellwood and Dizon 2008; Hung 2008; table 1; fig. 3). A key site here is Chaolaiqiao, on Shanyuan Bay, accurately dated by AMS C14 to 2200 BC and with redslipped pottery forming almost $100 \%$ of the assemblage, with virtually no cord marking or other type of decoration. By $2000 \mathrm{BC}$, this red-slipped plain ware tradition had spread to previously uninhabited Batanes as documented in Reranum and Torongan Caves on Itbayat. Pottery vessels in this phase commonly had pedestal bases and tall everted rims and lacked body decoration apart from the red slip (fig. $2 U, 2 \mathrm{~V}$ ). Reranum and Chaolaiqiao still have some residual cord marking (fig. 2R), and the close similarities in red-slipped pottery between these two sites raise the possibility that a direct migration from sites such as An Son in southeastern Taiwan to Itbayat could have occurred between 2200 and 2000 BC.

For northern Luzon (Philippines), current research on the lowest deposits beneath the late Neolithic shell mound at Nagsabaran (Hung 2008; Hung et al., forthcoming) suggests that both red-slipped plain ware and stamped pottery appeared together around $2000 \mathrm{BC}$ (see also Ogawa 2005). A closely related tradition of red-slipped and punctate/circlestamped pottery decoration is also reported from early sites such as Achugao and Unai Bapot on Saipan in the Mariana Islands, western Micronesia, where initial settlement across $2,300 \mathrm{~km}$ of open sea (the first truly long-distance sea voyage in human history) occurred from the northern Philippines at about 1500 BC (Butler 1995; Carson 2008; Clark et al. 2010; Hung et al., forthcoming). A similar co-occurrence of redslipped plain ware with small amounts of stamped and incised decoration also commenced at ca. 1300 BC at Bukit Tengkorak in Sabah, here with bark cloth beaters and trapezoidal crosssectioned adzes paralleled in Batanes, Taiwan, and Fujian (Chia 2003; Jiao 2007). Bukit Tengkorak also has Talasea (Kutau/Bao) obsidian from the Bismarck Archipelago in Near Oceania, thus illuminating two-way human movement on a remarkable scale (Bellwood 1989; Chia 2003).

In other parts of central and eastern Indonesia, the decorated pottery appears later than the red-slipped plain ware, 
similar to the situation in southeastern Taiwan and Batanes. Red-slipped plain ware is dated from ca. 1500 BC at Kamassi and Minanga Sipakko in West Sulawesi (Simanjuntak et al. 2008; incised pottery and obsidian from these sites is younger), and other sites in central and eastern Indonesia with early red-slipped plain ware include Kendeng Lembu in eastern Java, Uattamdi in Maluku, Leang Tuwo Mane'e in Talaud, possibly Paso in northern Sulawesi, and Madai Cave in Sabah (Bellwood 1997; fig. 3).

The above evidence comes together (table 1) to suggest that a red-slipped plain ware tradition of clear Taiwan origin was joined after 2000 BC by a very significant tradition of zoned incision with infilling by punctate or circle stamping, the punctate made by a multiple-toothed tool such as a tattooing chisel. Some sites have both plain and stamped pottery from the start; others appear to have an earlier horizon of plain ware only, but the picture is still obscure because so many assemblages are very small and come from caves and rock shelters. Perhaps the punctate and circle-stamping tradition was introduced from mainland southern China or Hainan (Rispoli 2008; H.-C. Hung, unpublished data), although it is not possible to rule out Taiwan as the immediate source on present evidence because examples occur there from Yuanshan and Yingpu contexts dating to ca. 1500-500 BC (e.g., Chang 1969, pls. 82D, 84D).

Similar punctate and dentate stamping is a very typical feature of Lapita pottery in western Melanesia (1350-750 BC; Green 2003) and occurs here with white lime or clay infilling of the designs, as in Luzon and the Marianas, where the greatest similarities occur (fig. 3). Punctate stamping with Lapita affinities is rare to absent in eastern Indonesia. In the Lapita sites in Oceania, the stamping apparently commenced everywhere at the base of the local Neolithic sequence, as in Luzon and possibly the Marianas, and it is likely that movement through the latter islands into the Bismarck Archipelago introduced some of the Lapita decorative repertoire into Oceania. No claim is made that Lapita origins occurred only via the Marianas, because multidirectional movements through Indonesia are also implied by the Bukit Tengkorak obsidian and could have involved populations speaking relatively undifferentiated languages still very close to PMP.

Different developments appear to have taken place in Sarawak, where rice husks in pottery dating from about 2200 BC onward in the cave of Gua Sireh (Beavitt, Kurui, and Thompson 1996; Ipoi 1993) are associated with paddle- or comb-impressed pottery with only rare red slip and no stamping. The Gua Sireh impression is paralleled in rim forms and decoration in Middle Neolithic assemblages in southern Taiwan (e.g., Li 1983) and Hong Kong (Meacham 1978: Sham Wan assemblages $\mathrm{F}$ and $\mathrm{C}$ ). I have also raised the possibility that the Gua Sireh assemblage could indicate a former Austroasiatic linguistic presence in Borneo (Bellwood 1997:117, 236-238), and current research on the Neolithic in southern Vietnam leaves this option open, especially for certain parallels with rice chaff-tempered pottery from sites such as An
Son in southern Vietnam (P. Bellwood, M. Oxenham, C. H. Bui, et al., unpublished manuscript). However, this is still an area of uncertainty that requires further research.

The above pottery data thus point to a secure ceramic sequence for much of Island Southeast Asia (except for Sarawak and perhaps Sumatra), within which combinations of red-slipped and stamped pottery spread from Taiwan and possibly other adjacent regions of the Asian mainland into Indonesia and western Oceania via the Philippines, with linguistically close populations moving in different directions at the same time. Influences from this tradition reached the Marianas and Lapita regions of Island Melanesia between 1500 and 1000 BC (fig. 3; table 1).

Debate has recently been expressed over whether the Neolithic assemblages carried from Taiwan into Island Southeast Asia and western Oceania constituted a "package" of coherently related material items (Donohue and Denham 2010). If there was such an Austronesian package, it was clearly polythetic in the sense of David Clarke (1968). Rice cultivation, domesticated pigs and dogs (see below), red-slipped pottery, earthenware spindle whorls, sawn and ground stone adzes with tanged or grooved butts and quadrangular to triangular cross sections, Taiwan slate and nephrite, notched pebble sinkers, stone bark cloth beaters, and a variety of shell, stone, or bone artifacts including bracelets, beads, and fishhooks can all be argued to have been carried from Taiwan into at least the Philippines and in many cases beyond (Bellwood and Dizon 2008; Hung 2008; fig. 2). Eventually, the domestic animals, pottery, stone adzes, bark cloth beaters, woodworking technology, canoe construction, and fishing gear, and perhaps even the working of nephrite (e.g., in Maori New Zealand), extended deep into Remote Oceania, although pottery making did not survive after about 2,000 years ago in Polynesia or much of Micronesia. Other items remained restricted in distribution-artifacts of Taiwan slate, for instance, are so far reported only from Batanes, and pottery spindle whorls apparently did not travel beyond Luzon.

My view is that no "package" concept can afford to be exclusive, and there will always be a danger that people will read far more into the concept than is necessary. Allowance must always be made for indigenous contributions to the suite of moving concepts and items, if and when they are required. The problem is that such contributions are often difficult to establish, especially from pre-Austronesian Island Southeast Asia and Oceania. Hard archaeological evidence as opposed to supposition does not support the claims for pre-Austronesian interaction networks made by Donohue and Denham (2010), for instance, or Bulbeck (2008), or in the form of Terrell's (2010) “ancient lagoons" hypothesis for early Holocene New Guinea. Ancient lagoons formed by high midHolocene sea levels were certainly not unique to New Guinea. Populations in southeastern coastal China experienced them as well. 


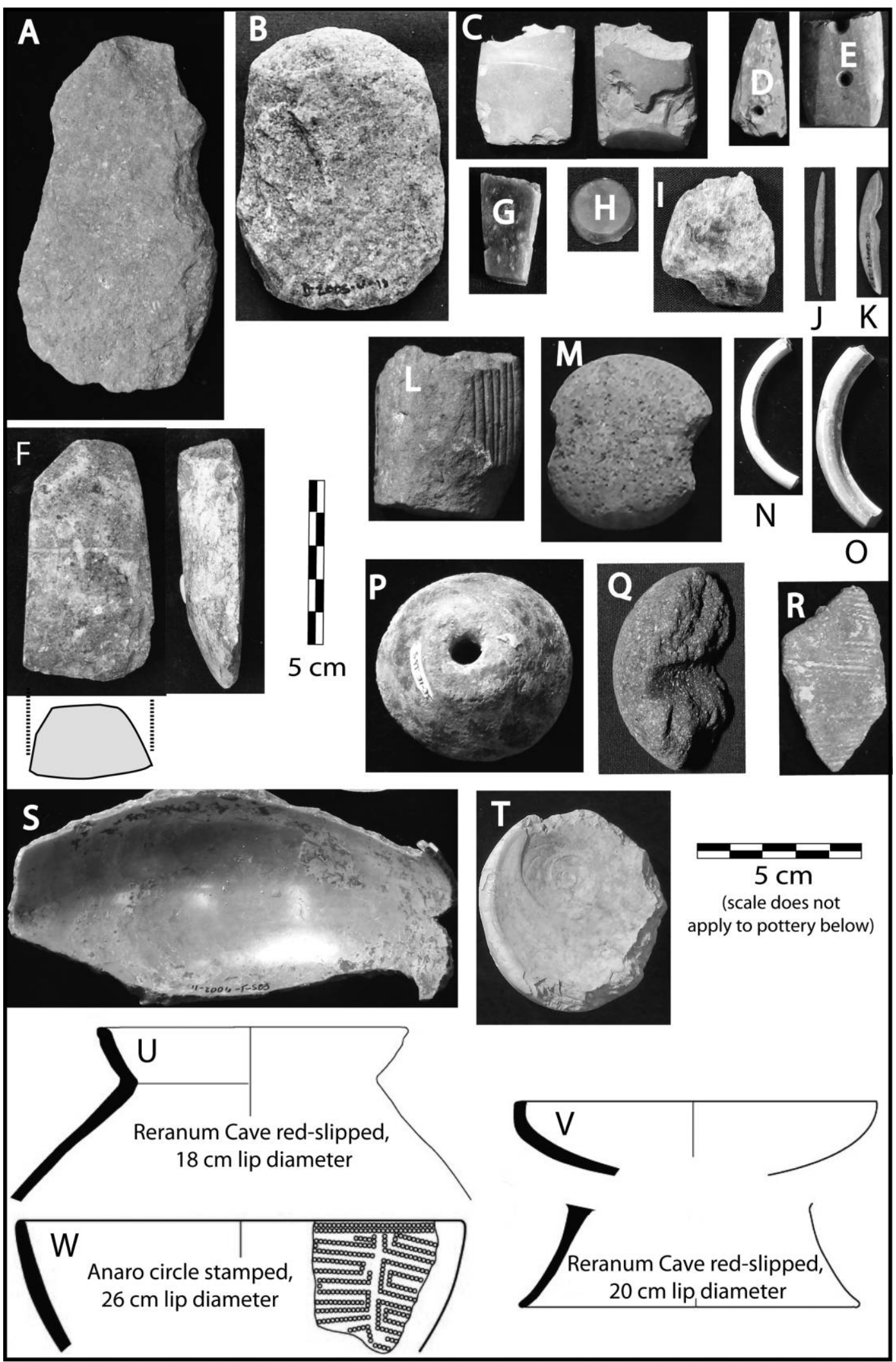




\section{How Significant Were Rice and Pigs?}

It has been suggested that the failure of rice cultivation to spread widely in perhumid equatorial eastern Indonesia or into prehistoric Oceania renders invalid any suggestion of Neolithic movements out of Taiwan (Oppenheimer and Richards 2002:289). But these authors fail to note that remains of rice and millet were universally absent from sites of the Dabenkeng phase in Taiwan (3500-2500 BC) until both were found in unprecedented carbonized quantities in hitherto unique waterlogged conditions dating to ca. $2800 \mathrm{BC}$ in the Nanguanli sites in the Tainan Science-Based Industrial Park (Tsang 2005; Tsang, Li, and Chu 2006). In fact, the list of sites in Island Southeast Asia in which evidence for rice has been found, particularly as a result of careful analysis of pottery or phytoliths, is rapidly increasing, especially in circumstances where carbonized macroremains are absent. For example, rice remains are present in pottery at Andarayan in the Cagayan Valley before 1400 BC (Snow et al. 1986). Rice phytoliths have been identified in the site of Kamassi in the Karama valley in western Sulawesi, but it is unclear whether they relate to food production (Anggraeni, personal communication). In Malaysian Borneo, rice remains including phytoliths have been reported dating variously between 2200
BC and AD 1 from Gua Sireh and Lubang Angin (see above) in Sarawak and Madai and Bukit Tengkorak in Sabah. For Sarawak, Doherty, Beavitt, and Kurui (2000) report the discovery of rice in pottery from a total of 35 sites. Strangely, however, Victor Paz (2002:279) identified charred remains of Dioscorea alata and possibly Colocasia esculenta, but no rice, in a large quantity of late prehistoric charcoal from Madai Cave 1 in Sabah, even though one hearth sample from the same site dating to ca. 2000 years ago, submitted to phytolith specialist Geoff Parr, yielded rice phytoliths in quantity. Situations such as this are puzzling and suggest that failure of rice remains to survive macroscopically need not imply a total absence. New excavations at Eluanbi in southern Taiwan have also yielded rice phytoliths in a situation where charcoal is absent (T. Cheng and L. Tsuo-Ting, personal communication, February 2009). As Pearsall (2003:274) notes for sites in Ecuador, and as I have noted many times in Southeast Asian field conditions, charcoal can disintegrate rapidly in seasonal tropical environments with strong cycles of wetting and drying.

Put simply, archaeologists working in Island Southeast Asia have probably failed to recognize cereal remains because of poor preservation conditions and lack of observational tech-

Figure 2. Artifacts from the Batanes Islands that have Taiwan affinities or actual Taiwan origins in the period $2200-800$ BC. The scales apply to all items except the pottery. $A$, "Hoe" of volcanic rock from Torongan Cave, Itbayat, ca. 1500-2000 BC. B, Bifacially flaked hoe of volcanic rock from Anaro, Itbayat, surface find. $C$, Tanged adze of metamorphic rock from Sunget, Batan, 1200-800 BC (cf. Duff 1970:115 for Yuanshan parallels and Chang 1969:165 for a Dabenkeng parallel). D, E, Taiwan slate point and point base from Anaro, surface finds (but such forms go back to the Dabenkeng early Neolithic in Taiwan; Chang 1969:54; Tsang, Li, and Chu 2006:90-91 for Youxianfang). F, Grooved adze of volcanic rock from Anaro, surface find (cf. Duff 1970:116 for Taiwan parallels). G, $H$, Sawn and drilled pieces of Taiwan nephrite from Anaro; these are surface finds, but similar fragments date from $1000 \mathrm{BC}$ onward in the site. $I$, Broken adze of Taiwan nephrite, Anaro, surface find. $J$, $K$, Bone bipoint and fishing gorge (of pig canine tooth) from Anaro, first millennium BC (cf. Li 1983, pl. 102 [Eluanbi III]; Tsang, Li, and Chu 2006:175). L, Broken bark cloth beater from Anaro; this form (type III of Cameron 2006) occurs in excavated context at Nanguanli in southwest Taiwan at ca. 2800 BC (Dabenkeng phase; Tsang, Li, and Chu 2006:91). M, Notched pebble net sinker from Savidug, Sabtang Island, ca. 800 BC; this form also occurs from Dabenkeng times onward in Taiwan (Tsang, Li, and Chu 2006:113). N, O, Conus and Trochus shell bracelets (cf. Li 1983, pl. 53 [Eluanbi III, southern tip of Taiwan, ca. $1000 \mathrm{BC}]$ ). P, Q, Baked clay spindle whorls from Anaro, surface finds; this form occurs from Middle Neolithic onward in Fujian and Taiwan (Cameron 2002; Tsang, Li, and Chu 2006: 192, Sanbaozhu). $R$, Fine-cord-marked sherd of Taiwan Middle Neolithic type from Reranum Cave, Itbayat, ca. 1500 BC. $S$, Chipped operculum of Turbo marmoratus, Savidug, 1000-5000 BC (Li 1983, e.g., pl. 30, illustrates parallels from Taiwan preceramic onward). T, "Scoop" of Turbo marmoratus, Savidug, 1000-500 BC; for an exact parallel from Eluanbi III, see Li (1983, pl. 93). $U, V, W$, Batanes pottery, 1500-800 BC. (Artifacts reproduced courtesy of the National Museum of Philippines.) 
Table 1. Archaeological Phases of the Neolithic in Taiwan and the Northern Philippines from before 3500 BC to $500 \mathrm{BC}$

\begin{tabular}{ll}
\hline Phase & \multicolumn{1}{c}{ Description } \\
\hline 1 (before 3500 BC) & $\begin{array}{c}\text { Flaked lithics and shell tools, no evidence for Neolithic technology (such as stone sawing, grinding, } \\
\text { use of nephrite, or pottery) } \\
\text { Dabenkeng and "fine-cord-marked" phases in Taiwan: appearance of Neolithic technology with use of } \\
\text { nephrite and slate, rice and foxtail millet cultivation, and transition from cord-marked to red- } \\
\text { slipped plain ware pottery. No known expansion south of Taiwan occurred at this time, but Sum- } \\
\text { merhayes and Anderson (2009) raise the possibility of movement into the nearby Ryukyu Islands, } \\
\text { southern Japan } \\
\text { First human settlement of Batanes and Luzon from southern Taiwan, about 2200 BC, followed by a } \\
\text { considerable flow of material culture, especially red-slipped plain ware pottery, from Taiwan into } \\
\text { the Philippines and onward into Island Southeast Asia. Associated with this was a spread of } \\
\text { stamped pottery decoration from ultimate mainland Asian sources, which traveled with the red- } \\
\text { slipped plain ware into the Philippines and onward to the Mariana Islands in western Micronesia } \\
\text { and the Lapita zone of Island Melanesia and western Polynesia. This spread appears to have had } \\
\text { only limited impact in Taiwan but a major impact in the northern Philippines } \\
\text { Increasing evidence for frequent Taiwan-Batanes-Philippines and across-the-South-China-Sea contacts } \\
\text { in both directions, particularly involving Taiwan nephrite (Hung and Bellwood 2010; Hung et al. } \\
\text { 2007) }\end{array}$ \\
\hline (first millennium BC)
\end{tabular}

nology. Furthermore, the above-listed Borneo sites, apart from Gua Sireh, are far from fertile rice-growing terrain and, in the case of the Niah Caves (Barker 2005), supported a continuing hunter-gatherer population (Punan) until the Iban incursions of the nineteenth century. It is likely that many of the Neolithic and Iron Age burials in the upper Niah stratigraphy were of people not native to the immediate area (Valentine, Kamenov, and Krigbaum 2008), and so the traces of rice found in their pots need cause no surprise. Caves in marginal agricultural terrain such as Niah are of questionable relevance for any discussion of agricultural origins in Island Southeast Asia. Real data on agricultural prehistory are far more likely to come from waterlogged alluvial and coastal sites such as those recently discovered in Taiwan, but such are at present undiscovered in the islands to the south.

The failure of rice cultivation to spread into Oceania is not hard to explain. Dewar (2003) discusses reasons of climatic variability for a relative absence (or nonsignificance) of rice in many parts of northern and eastern Island Southeast Asia, suggesting that El Niño-Southern Oscillation (ENSO)-related rainfall unreliability was a major reason for its failure to spread into Oceania. Paz (2002), as noted above, refers to day-length considerations. Island Southeast Asia encompasses $30^{\circ}$ of latitude, from subtropical regions with strong seasonality of rainfall distribution into equatorial regions that were uniformly hot and perhumid all year round. We can hardly expect that people would always have continued to grow rice when more suitable fruits and tubers were available, just as farming populations moving from the Indus into the Ganga Valley at about 3000 BC eventually adopted rice and other monsoon crops and allowed their West Asian winter crops to decrease in significance (Bellwood 2005:87; Fuller 2011). So far, our attempts to identify rice in phytolith samples from Batanes have not been successful, but because rice was apparently not grown at European contact on Batan (Dampier 1687, in Blair and Robertson 1903-1909, vol. 38:98), we would not necessarily expect to find it, even though it is grown today as a minor monsoon crop in upland fields. The Batanes Islands have no flat alluvial land and no high-level water sources that could support terrace farming in the manner of the famous Ifugao terraces at Banaue in northern Luzon. My suspicion is that the Batanes formed a filter against a spread of rice in the early years of Austronesian expansion and that it became significant only when settlers reached the broad alluvial landscapes of the Cagayan Valley and other parts of Luzon. Within much of the Philippines and Indonesia, Neolithic populations in mid-Holocene-drowned coastal landscapes (Bellwood et al. 2008) that lacked good alluvial rice soils moved expectably toward fruits and tubers for subsistence and doubtless encountered these species when they were already under exploitation by indigenous food gatherers.

The domestication of the pig in Island Southeast Asia is currently a topic of considerable debate (Larson et al. 2007, 2010) rendered complex by the wide distribution of native suids in mainland Asia, western Indonesia (Sundaland), and Sulawesi. Pig bones are widespread in Neolithic sites in Taiwan and are common in the lower Neolithic layer at Nagsabaran in the Cagayan Valley, where Piper has identified teeth of domesticated Sus scrofa directly AMS dated before 2000 BC (Piper et al. 2009). These pigs predate, perhaps by many centuries, the introduction of the so-called Pacific clade of pigs of southern China or northern Indochina origin into Lapita Melanesia. Unfortunately, the oldest Batanes sites, Reranum and Torongan Caves, contain no animal bone, but pig was present by 1200 BC in Sunget on Batan.

At this stage, it is not clear to what degree pigs traveled with Neolithic migrants in Island Southeast Asia or how many separate domestications of local species occurred (Larson 2011). It seems that pigs were not carried from Luzon to the Marianas in prehistoric times, so they did not enter the Lapita 


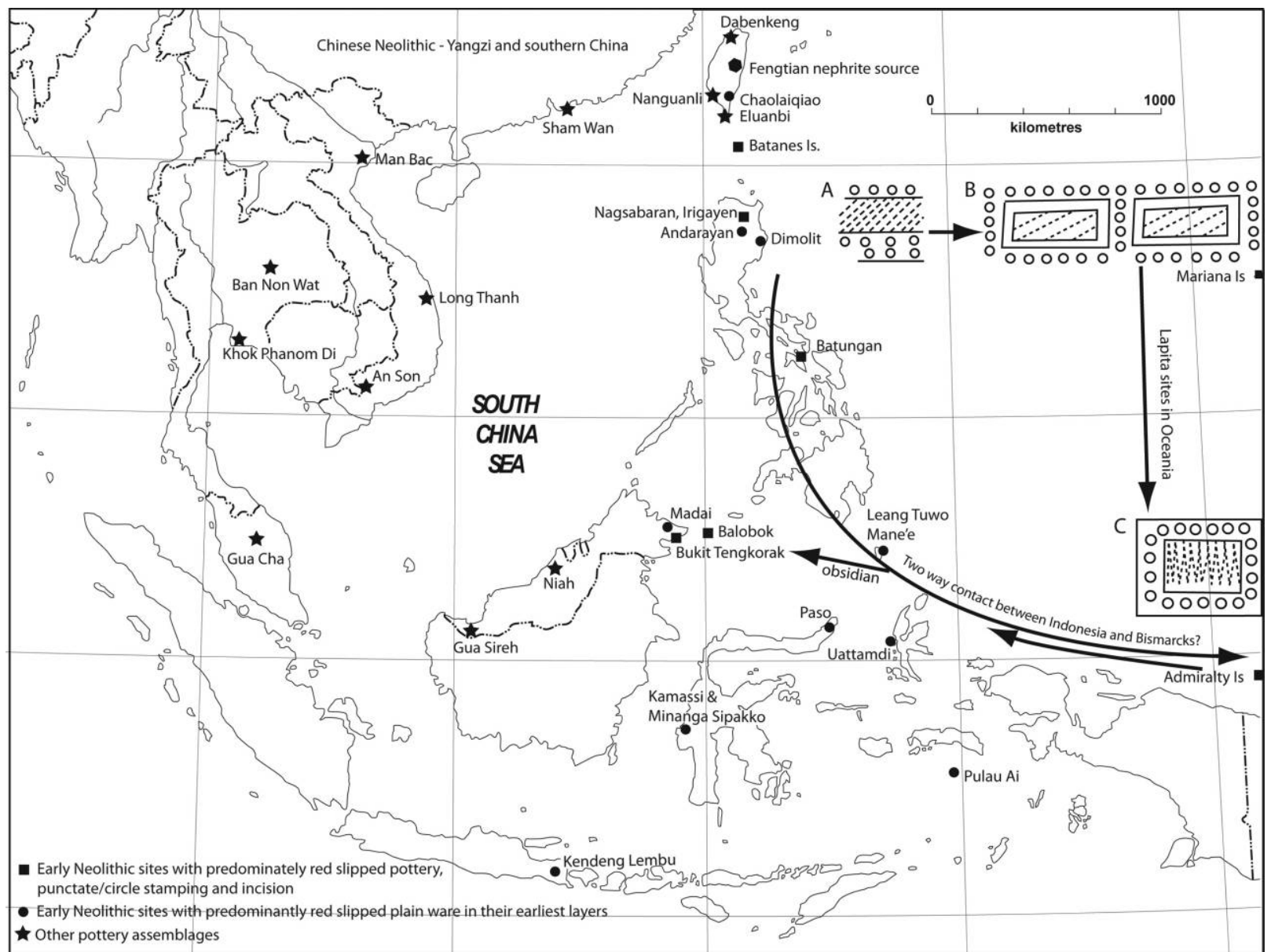

Figure 3. Pottery surface decoration in Southeast Asia, 2500-1000 BC. Inset motifs of incised and stamped decoration on sherds: $A$, Nagsabaran, northern Luzon (courtesy Hsiao-chun Hung); B, Achugao, Saipan (drawn from a photo provided by Brian Butler; see Butler 1995, fig. 12-6b); $C$, Lapita, New Caledonia (redrawn with permission from Sand 1999:46).

zone by this route. It is also quite possible that pre-Neolithic populations translocated indigenous wild pig species to resource-poor islands such as Flores in eastern Indonesia (Dobney et al. 2008), just as they might have translocated marsupials out of New Guinea (Flannery et al. 1998).

\section{The Nephrite Trail}

In Taiwan, nephrite (jade) tools and ornaments have been identified from more than 100 sites dating between 3000 BC and AD 500 (Hung et al. 2007). Taiwan nephrite is generally green in color and was exploited from deposits at Fengtian, located at the northern end of the eastern rift valley of Taiwan inland from the city of Hualian. This appears to have been the only nephrite source utilized in prehistoric Taiwan. Fengtian nephrite has recently been subjected to a detailed sourcing program by Yoshiyuki Iizuka at the Institute of Earth Sciences,
Academia Sinica, Taipei, using a low-vacuum scanning electron microscope equipped with an energy-dispersive $\mathrm{x}$-ray spectrometer (Iizuka and Hung 2005; Iizuka et al. 2005). It can be identified with confidence in terms of the chemistry of its matrix and its zinc-chromite inclusion minerals. All green jade artifacts tested from Taiwan and the Philippines are from the Fengtian source (but Luzon also has at least one separate white nephrite source).

Jade working was most probably introduced into Taiwan from southern China, where it was present in the Yangzi Basin as early as 5000 BC. In Taiwan, sawn nephrite adzes appear in the Dabenkeng phase (ca. 3000 BC; Hung 2004), and the long-lasting tradition of grooving, snapping, drilling, and polishing nephrite later developed into the remarkable funerary assemblages of Beinan in southeastern Taiwan (ca. 1500-500 BC), with pendants (some anthropomorphic), penannular 
earrings (some with four circumferential projections), bellshaped and tubular beads, perforated arrowheads and spearheads, and adzes (Lien 2002). Worked nephrite occurs with the red-slipped pottery referred to above from Chaolaiqiao in southeastern Taiwan (2200 BC), and it seems likely that some of the earliest Neolithic settlers from Taiwan could have carried it to the northern Philippines.

The oldest sites in Batanes (Reranum and Torongan caves) so far lack nephrite, but an adze of Fengtian nephrite was found at Sunget (ca. 1200 BC), and several surface finds of Taiwan sawn nephrite stone adzes come from Anaro on Itbayat Island. Stone adzes of other metamorphic rocks from Batanes and Luzon also show a preference for sawing rather than flaking in manufacture. More significantly, in terms of date, parts of two Fengtian nephrite bracelets have been recovered from the base of Nagsabaran (ca. 2000-1500 BC) in the Cagayan Valley. In Taiwan, this form is most commonly found in the Middle Neolithic phase of fine-cord-marked pottery before 2000 BC. For instance, 25 were recovered, in some cases in association with burials, from the Niuchouzi phase site of Youxianfang near Tainan in southwestern Taiwan. This site is radiocarbon dated between 1850 and 1350 BC (Tsang, Li, and Chu 2006) and is thus roughly contemporary with the lower layer in Nagsabaran. Such bracelets are uncommon in the post-1500 BC Beinan culture (Lien 2002).

In later times, a flourishing movement of ornaments of Fengtian nephrite linked a number of Iron Age (ca. 300 BC$\mathrm{AD}$ 500) sites throughout the Philippines with Sarawak, southern Vietnam, peninsular Thailand, and possibly eastern Cambodia (Hung et al. 2007). This later trade/exchange network is not of direct concern for the earlier phases of Austronesian dispersal, but it does emphasize that Austronesianspeaking communities never lost contact with Taiwan and in this regard is very significant. Fengtian nephrite was exported for upward of 2,000 years through the Philippines and onward to further regions on a fairly regular basis and presumably by people who mostly shared an Austronesian linguistic heritage.

\section{Out of Taiwan into the Philippines: A Summary}

Four factors render a southward movement of Neolithic material culture from Taiwan into the northern Philippines at about 2000 BC a virtual certainty. (1) Strong parallels in material culture between 2200 and 1500 BC link southern Taiwan and the northern Philippines, reinforced by the movement of artifacts of Taiwan slate and positively sourced Taiwan nephrite. The synchronous changes in pottery decoration that link southeast Taiwan, the Batanes Islands, and Luzon, from a predominance of cord marking in Taiwan only, through a dominance of red-slipped pottery and into a slightly later phase of red-slipped and stamped pottery are especially important. (2) Taiwan has chronological priority of the artifact types concerned involving an unbroken continuity since at least $3000 \mathrm{BC}$ in cord-marked and red-slipped pottery, and many of the items are illustrated in figure 2. To these can be added the oldest radiocarbon dates for rice and millet, domesticated dogs, and probably pigs in Southeast Asia. (3) There is an absence of closely related Neolithic material culture before $1500 \mathrm{BC}$ in Indonesia, and there are deep and significant differences in most aspects of Neolithic (pre-Sa Huynh) material culture between Vietnam and the Philippines before 1000 BC. (4) The absence of an earlier population in the Batanes Islands implies a movement of people to establish colonization, not an adoption of Neolithic material culture by an indigenous hunter-gatherer population (as probably happened to a degree in the Peñablanca Caves in Luzon; Mijares 2006).

From an archaeological perspective, the progression of Neolithic material culture assemblages of ultimate East Asian/ Taiwan origin through the regions settled by ancestral Austronesian speakers required about 4,000 years to unfold from Taiwan to New Zealand, perhaps 6,000 years if commencing in southern China (fig. 3). Populations already resident in Island Southeast Asia and Melanesia contributed cultural capital in the form of some shell-artifact technologies (especially flaked-shell tools), tuber and fruit crops of western Pacific (especially New Guinea) origin, flaked lithic traditions (found commonly mixed with Neolithic assemblages in Indonesian caves), and even translocated species of marsupials in some islands close to New Guinea. As to the origins of the economic and technological complexes that fueled Austronesian dispersal in the first instance, we must look to southern coastal China (Fuller, Harvey, and Qin 2007; Hung 2008; Jiao 2007; Rispoli 2008; Zhang and Hung 2008, 2010). Food production, maritime knowledge, and perhaps even domino effects from the movements of Yangzi Basin rice farmers all played roles here. What is clear is that the Neolithic complex that spread through Island Southeast Asia and into the Pacific emanated from southern China via Taiwan and then presumably via the Philippines and Borneo. It manifestly did not originate from the south.

In conclusion, it is possible to focus on Taiwan and the Philippines at the end of the third millennium BC in order to identify the start of a migration, by both land and sea, of speakers of Malayo-Polynesian languages and of the carriers of a broad range of Neolithic material culture with food production. Both of these spreads are likely to have been two sides of one "event" involving a single ethnolinguistic and genetic population in the final resort, albeit one that was constantly adapting and interacting, as all humans do. The migration originated more deeply in southern China and eventually encompassed warm temperate through equatorial latitudes in the Northern Hemisphere, out again into temperate latitudes (New Zealand) in the Southern Hemisphere, thus passing through some major zones of environmental and resource difference as well as through preexisting populations with their own long-established cultures and languages, particularly in western Oceania. One of the results of this equa- 
torial transition appears to have been an abandonment of cereal (rice and millet) cultivation in Indonesia in favor of the fruit-and-tuber-based plant economy that characterized the Pacific Islands.

Why did the Austronesian dispersal occur? Within eastern Taiwan, the archaeological record indicates a marked increase in the number of archaeological sites after 2500 BC (Hung 2008), so population growth and a need for new cultivation land come to mind, given that southeastern Taiwan is a rugged area with low agricultural potential. But early Austronesians moved on to settle new islands very rapidly in terms of both archaeology and comparative linguistics (Pawley 1999). For instance, colonists spread $8,000 \mathrm{~km}$ from the Batanes Islands to Samoa in less than 1,000 years, beyond which a slowdown occurred, perhaps due in part to the nonemergence of Pacific atolls until much later in time (Dickinson 2003). This rapid movement to western Polynesia surely reflected a reliance on both maritime and lowland agricultural resources, the latter greatly reduced in extent by the drowning of the most fertile alluvial and coastal soils as the sea attained its maximum midHolocene sea level (Bellwood et al. 2008). This would have rendered good coastal and alluvial farmland scarce in the early centuries of Austronesian migration, creating deep estuaries and steep coastlines against rugged island interiors, at least until forest clearance caused soil aggradation to build up fertile lowlands. Advancing maritime technology also fueled the Austronesian spread, with the earliest evidence for canoes and paddles in this region coming from coastal central China during the early Holocene.

\section{Can the Austronesian Dispersal Inform Us about Dispersals of Languages and Farming in Other Parts of the World?}

The reality of Austronesian dispersal via Taiwan and the Philippines is powerfully reinforced by evidence from three independent research areas: linguistics, archaeology, and human biology. This dispersal did not involve an autonomous origin of food production on present evidence, which admittedly is slight; rather, it was a peripheral result of the developments of food production farther north in mainland East Asia and farther east in New Guinea. There is much uncertainty here, and little mileage would be gained by debating whether Austronesian languages or peoples can be traced directly into the Yangzi Basin. Domino effects could have occurred, even localized language shift (because language shift was surely always localized under Neolithic social conditions), as well as direct transmission.

What is clear, however, is that the Austronesian dispersal to Taiwan and beyond between 3000 and 1000 BC occurred at the same time that agricultural populations in China and Taiwan attained very high demographic densities, especially during the Longshan and Shang periods in China itself. Austronesian dispersal did not originate as an independent prod- uct of forager activity in the archipelagoes of Island Southeast Asia during the early Holocene millennia of sea-level rise. Neither could it have been caused only by maritime knowledge or unusual concatenations of ENSO events (Anderson et al. 2006). Such factors no doubt helped, and of course without their rafts or canoes, Austronesians would presumably not have traveled far. But without the demographic impetus and technological advancement provided by East Asian food production, this dispersal could never have occurred, at least not through the inhabited portions of Island Southeast Asia. The previously empty islands in the Pacific would in many cases have been too small, isolated, and impoverished in terrestrial resources for long-term low-technology forager settlement. Early Jomon people in Japan and early Australians had rudimentary sea craft in some regions at least, but as far as we know, their forager economies did not lead to maritime population dispersal over large distances. Neither of these populations attempted to colonize the Pacific.

In conclusion, the Austronesian dispersal was little different in a demographic and causative sense from other early farming dispersals across the Eurasian, African, and American continents. The maritime setting is unusual, but we have no data to suggest that Austronesians ever entirely gave up food production, except in equatorial rainforests in Borneo and frosty southern New Zealand. Doubtless, Austronesian food production varied in intensity-many Austronesians are low-level food producers in Bruce Smith's $(2001,2011)$ terms todaybut this need not be a universally ancestral condition. Inability to find prolific evidence for cultivated crops in archaeological sites does not mean that we must throw out all the comparative linguistic reconstructions of an early Austronesian agricultural vocabulary. Naive birds, fishing, and westerly winds doubtless assisted many individual episodes of colonization but alone did not lead to Pacific colonization beyond Near Oceania.

\section{Acknowledgments}

The reported archaeological research in the Batanes Islands, Cagayan Valley, and southern Vietnam was funded by the Australian Research Council, the Wenner-Gren Foundation for Anthropological Research, and the Chiang Ching-Kuo Foundation (Taipei). It involved crews from the National $\mathrm{Mu}$ seum of the Philippines, University of the Philippines, Center for Archaeological Studies (Ho Chi Minh City), and Australian National University. A monograph on the Batanes research is in preparation, to be published by ANU E Press.

\section{References Cited}

Addison, D., and E. Matisoo-Smith. 2010. Rethinking Polynesian origins: a West Polynesia triple-I model. Archaeology in Oceania 45:1-12.

Ammerman, A., and L. L. Cavalli-Sforza. 1973. A population model for the diffusion of early farming in Europe. In The explanation 
of culture change. C. Renfrew, ed. Pp. 343-357. London: Duckworth.

$\rightarrow$ Anderson, A., J. Chappell, M. Gagan, and R. Grove. 2006. Prehistoric maritime migration in the Pacific Islands: an hypothesis of ENSO forcing. Holocene 16:1-6.

$\rightarrow$ Barker, G. 2005. The archaeology of foraging and farming at Niah Cave, Sarawak. Asian Perspectives 44:90-106.

Beavitt, P., E. Kurui, and G. Thompson. 1996. Confirmation of an early date for the presence of rice in Borneo. Borneo Research Bulletin 27:29-37.

Bellwood, P. 1989. Archaeological investigations at Bukit Tengkorak and Segarong, southeastern Sabah. Bulletin of the Indo-Pacific Prehistory Association 9:122-162.

. 1996. Phylogeny and reticulation in prehistory. Antiquity 70: 881-890.

. 1997. Prehistory of the Indo-Malaysian Archipelago. Rev. edition. Honolulu: University of Hawaii Press.

$\rightarrow-$. 2001. Early agriculturalist population diasporas? farming, languages and genes. Annual Review of Anthropology 30:181-207.

. 2005. First farmers. Oxford: Blackwell.

2008. Archaeology and the origins of language families. In Handbook of archaeological theories. A. Bentley, H. Maschner, and C. Chippindale, eds. Pp. 225-243. Lanham, MD: Altamira.

- 2009a. La diffusion des populations d'agriculteurs dans le monde. In La révolution néolithique dans le monde. Jean-Paul Demoule, ed. Pp. 239-262. Paris: CNRS.

$\rightarrow$ - 2009b. The dispersals of established food-producing populations. Current Anthropology 50:621-626.

Bellwood, P., G. Chambers, M. Ross, and H.-C. Hung. Forthcoming. Are cultures inherited? multidisciplinary perspectives on the origins and migrations of Austronesian speaking peoples prior to 1000 BC. In Investigating archaeological cultures: material culture, variability and transmission. B. Roberts and M. van der Linden, eds. Dordrecht: Springer.

Bellwood, P., and E. Dizon. 2005. The Batanes archaeological project and the out of Taiwan hypothesis for Austronesian dispersal. Journal of Austronesian Studies 1:1-33.

. 2008. Austronesian cultural origins: out of Taiwan, via thr Batanes Islands, and onwards to western Polynesia. In Past human migrations in East Asia: matching archaeology, linguistics and genetics. Alicia Sanchez-Mazas, Roger Blench, Malcolm D. Ross, Ilii Peiros, and Marie Lin, eds. Pp. 23-39. London: Routledge.

Bellwood, P., and M. Oxenham. 2008. The expansions of farming societies and the role of the Neolithic demographic transition. In The Neolithic demographic transition and its consequences. JeanPierre Bocquet-Appel and Ofer Bar-Yosef, eds. Pp. 13-34. Dordrecht: Springer.

Bellwood, P., J. Stevenson, E. Dizon, A. Mijares, G. Lacsina, and E. Robles. 2008. Where are the Neolithic landscapes of Ilocos Norte? Hukay 15:25-38.

Blair, E. H., and J. A. Robertson. 1903-1909. The Philippine Islands 1493-1898, 55 vols. Cleveland, OH: Clark.

Blust, R. 1977. The proto-Austronesian pronouns and Austronesian subgrouping: a preliminary report. Working Papers in Linguistics, University of Hawai'i 9(2):1-15.

- 1999. Subgrouping, circularity and extinction: some issues in Austronesian comparative linguistics. In Selected papers from the eighth international conference on Austronesian linguistics. E. Zeitoun and P. J.-K. Li, eds. Pp. 31-94. Taipei, Taiwan: Academia Sinica.

- 2009. The Austronesian languages. Canberra: Pacific Linguistics.

Bocquet-Appel, J.-P. 2011. The agricultural demographic transition during and after the agriculture inventions. Current Anthropology 52(suppl. 4):S497-S510.
Bulbeck, D. 2008. An integrated perspective on the Austronesian diaspora. Australian Archaeology 67:31-52.

Butler, B. 1995. Archaeological investigations in the Achugao and Matansa areas of Saipan, Mariana Islands. Micronesian Archaeological Survey report no. 30. Saipan: Micronesian Archaeological Survey.

Cameron, J. 2002. Textile technology and Austronesian dispersals. In The archaeology of Lapita dispersal in Oceania. G. Clark, A. Anderson, and T. Vunidilo, eds. Pp. 177-181. Canberra: Pandanus.

- 2006. Trans-oceanic transfer of bark-cloth technology from South China-Southeast Asia to Mesoamerica? In Islands of enquiry. G. Clark, F. Leach, and S. O'Connor, eds. Pp. 203-210. Canberra: Australian National University E Press.

Carson, M. 2008. Refining earliest settlement in Remote Oceania. Journal of Island and Coastal Archaeology 3:115-139.

Chagnon, A. 1992. Yanomamö. Fort Worth, TX: Harcourt Brace Jovanovich.

Chang, K. C. 1969. Fengpitou, Tapenkeng and the prehistory of Taiwan. Publications in Anthropology 73. New Haven, CT: Yale University Press.

Chia, S. 2003. The prehistory of Bukit Tengkorak. Sabah Museum Monograph 8. Kota Kinabalu: Sabah Museum.

Clark, G., F. Petchey, O. Winter, M. Carson, and P. O’Day. 2010. New radiocarbon dates from the Bapot-1 site in Saipan and Neolithic dispersal by stratified diffusion. Journal of Pacific Archaeology 1(1):21-35.

Clarke, D. 1968. Analytical archaeology. London: Methuen.

Cohen, D. J. 2011. The beginnings of agriculture in China: a multiregional view. Current Anthropology 52(suppl. 4):S273-S293.

Cox, M. 2008. The genetic environment of Melanesia: clines, clusters and contact. In Population genetics research progress. V. T. Koven, ed. Pp. 45-83. New York: Nova Science.

Cox, M., T. M. Karafet, J. S. Lansing, H. Sudoyo, and M. F. Hammer. 2010. Autosomal and X-linked single nucleotide polymorphisms reveal a steep Asian-Melanesian ancestry cline in eastern Indonesia. Proceedings of the Royal Society B 277:1589-1596.

Denham, T. 2011. Early agriculture and plant domestication in New Guinea and Island Southeast Asia. Current Anthropology 52(suppl. 4):S379-S395.

Dewar, R. 2003. Rainfall variability and subsistence systems in Southeast Asia and the western Pacific. Current Anthropology 44:369388 .

Dickinson, W. 2003. Impact of mid-Holocene hydro-isostatic highstand in regional sea level on habitability of islands in Pacific Oceania. Journal of Coastal Research 19:489-502.

Dobney, K., A. Ervynck, U. Albarella, and P. Rowley-Conwy. 2008. The transition from wild boar to domestic pig in Eurasia. In Pigs and humans: 10,000 years of interaction. U. Albarella, K. Dobney, A. Ervynck, and P. Rowley-Conwy, eds. Pp. 57-82. Oxford: Oxford University Press.

Doherty, C., P. Beavitt, and E. Kurui. 2000. Recent observations of rice temper in pottery from Niah and other sites in Sarawak. Bulletin of the Indo-Pacific Prehistory Association 20:147-152.

Donohue, M., and T. Denham. 2010. Farming and language in Island Southeast Asia: reframing Austronesian history. Current Anthropology 51:223-256.

Duff, R. 1970. Stone adzes of Southeast Asia. Christchurch: Canterbury Museum.

Flannery, T. F., P. Bellwood, J. P. White, T. Ennis, G. Irwin, K. Schubert, and S. Balasubramanian. 1998. Mammals from Holocene archaeological deposits on Gebe and Morotai islands, Northern Moluccas, Indonesia. Australian Mammalogy 20(3):391-400.

Freeman, D. 1970. Report on the Iban. London: Athlone.

Friedlaender, J., F. Friedlaender, F. A. Reed, K. K. Kidd, J. R. Kidd, G. K. Chambers, R. A. Lea, et al. 2008. The genetic structure of Pacific Islanders. PLoS Genetics 4(1):e19, doi:10.1371/journal .pgen.0040019. 
Fuller, D., E. Harvey, and L. Qin. 2007. Presumed domestication? Antiquity 81:316-331.

Fuller, D. Q. 2011. Finding plant domestication in the Indian subcontinent. Current Anthropology 52(suppl. 4):S347-S362.

$\rightarrow$ Gray, R., A. Drummond, and S. Greenhill. 2009. Language phylog $\rightarrow$ enies reveal expansion pulses and pauses in Pacific settlement. Science 323:479-483.

Green, R. 2003. The Lapita horizon and traditions: signature for one set of Oceanic migrations. In Pacific archaeology: assessments and prospects. C. Sand, ed. Pp. 95-120. Le cahiers de l'archéologie en Nouvelle-Calédonie, vol. 15. Nouméa, New Caledonia: Departement Archéologie, Service des musées et du patrimoine de Nouvelle-Calédonie.

$\rightarrow$ Heggerty, P., and D. Beresford-Jones. 2010. Agriculture and language dispersals: limitations, refinements, and an Andean exception? Current Anthropology 51:163-192.

Hung, H.-C. 2004. A sourcing study of Taiwan stone adzes. Bulleti $\rightarrow$ of the Indo-Pacific Prehistory Association 24:57-70.

- 2005. Neolithic interaction between Taiwan and northern Luzon: the pottery and jade evidences from the Cagayan Valley. Journal of Austronesian Studies 1(1):109-134.

. 2008. Migration and cultural interaction in southern coasta China, Taiwan and the Northern Philippines, 3000 BC to AD 1. $\mathrm{PhD}$ thesis, Australian National University, Canberra.

Hung, H.-C., and P. Bellwood. 2010. Movement of raw materials and manufactured goods across the South China Sea after 500 BCE: from Taiwan to Thailand, and back. In 50 years of archaeology in Southeast Asia: essays in honour of Ian Glover. B. Bellina, L. Bacus, O. Pryce, and J. Wisseman Christie, eds. Pp. 234-243. Bangkok: River.

Hung, H-C., M. Carson, P. Bellwood, F. Campos, P. Piper, E. Dizon, M. Bolunia, M. Oxenham, and C. Zhang. Forthcoming. The first settlement of Remote Oceania: Luzon to the Marianas. Antiquity

$\rightarrow$ Hung, H.-C., Y. Iizuka, P. Bellwood, K. D. Nguyen, B. Bellina, P. Silapanth, E. Dizon, R. Santiago, I. Datan, and J. Manton. 2007. Ancient jades map 3000 years of prehistoric exchange in Southeast Asia. Proceedings of the National Academy of Sciences of the USA 104:19745-19750.

Hunley, K., M. Dunn, E. Lindström, G. Reesink, A. Terrill, M. E. Healy, G. Koki, et al. 2008. Genetic and linguistic coevolution ir $\rightarrow$ Northern Island Melanesia. PLoS Genetics 4(10):e1000239, doi: 10.1371/journal.pgen.1000239.

Iizuka, Y., P. Bellwood, H.-C. Hung, and E. Dizon. 2005. A nondestructive mineralogical study of nephritic artifacts from Itbaya Island, Batanes, northern Philippines. Journal of Austronesian Studies 1(1):83-108.

Iizuka, Y., and H.-C. Hung. 2005. Archaeomineralogy of Taiwan nephrite: sourcing study of nephrite artifacts from the Philippines $\rightarrow$ Journal of Austronesian Studies 1(1):35-80.

Ipoi, D. 1993. Archaeological excavations at Gua Sireh (Serian) and Lubang Angin (Gunung Mulu National Park), Sarawak, Malaysia. Special monograph 6, Sarawak Museum Journal.

Jiao, T. 2007. The Neolithic of southeast China. Youngstown, NY: Cambria.

Jing, Y., and R. Campbell. 2009. Recent archaeometric research on "the origins of Chinese civilisation." Antiquity 83:96-109.

$\rightarrow$ Kayser, M. 2010. The human genetic history of Oceania: near and remote views of dispersal. Current Biology 20(4):R194-R201, doi: 10.1016/j.cub.2009.12.004.

$\rightarrow$ Kayser, M., Y. Choi, M. van Oven, S. Mona, S. Brauer, R. J. Trent, D. Suarkia, et al. 2008a. The impact of the Austronesian expansion: evidence from mtDNA and Y chromosome diversity in the Admiralty Islands of Melanesia. Molecular Biology and Evolution 25: 1362-1374.

$\rightarrow$ Kayser, M., O. Lau, K. Saar, S. Brauer, X. Wang, P. Nürnberg, R. J. Trent, and M. Stoneking. 2008b. Genome-wide analysis indicates more Asian than Melanesian ancestry of Polynesians. American Journal of Human Genetics 82:194-198.

Kelly, R. 1985. The Nuer conquest. Ann Arbor: University of Michigan Press.

Kimura, R., J. Ohashi, Y. Matsumura, M. Nakazawa, T. Inaoka, R. Ohtsuka, M. Osawa, and K. Tokunaga. 2008. Gene flow and natural selection in oceanic human populations inferred from genomewide SNP typing. Molecular Biology and Evolution 25:1750-1761.

Lansing, S., T. Karafet, J. Schoenfelder, and M. Hammer. 2008. A DNA signature for the expansion of irrigation in Bali? In Past human migrations in East Asia: matching archaeology, linguistics and genetics. Alicia Sanchez-Mazas, Roger Blench, Malcolm D. Ross, Ilia Peiros, and Marie Lin, eds. Pp. 376-394. London: Routledge.

Larson, G. 2011. Genetics and domestication: important questions for new answers. Current Anthropology 52(suppl. 4):S485-S495.

Larson, G., T. Cucchi, M. Fujita, E. Matisoo-Smith, J. Robins, A. Anderson, B. Rolett, et al. 2007. Phylogeny and ancient DNA of Sus provides insights into Neolithic expansion in Island Southeast Asia and Oceania. Proceedings of the National Academy of Sciences of the USA 104(12):4834-4839.

Larson, G., R. Liu, X. Zhao, J. Yuan, D. Fuller, L. Barton, K. Dobney, et al. 2010. Patterns of East Asian pig domestication, migration, and turnover revealed by modern and ancient DNA. Proceedings of the National Academy of Sciences of the USA 107(17):7686-7691.

Li, K.-C. 1983. Report of archaeological investigations in the O-LuanPi Park at the southern tip of Taiwan. Taipei: Department of Anthropology, National Taiwan University. [In Chinese.]

Lien, Chao-mei. 2002. The jade industry of Neolithic Taiwan. Bulletin of the Indo-Pacific Prehistory Association 22:55-62.

Meacham, W., ed. 1978. Sham Wan, Lamma Island. Journal monographs 3. Hong Kong: Hong Kong Archaeological Society.

Mijares, A. S., F. Détroit, P. Piper, R. Grün, P. Bellwood, M. Aubert, G. Champion, N. Cuevas, A. De Leon, and E. Dizon. 2010. New evidence for a 67,000-year-old human presence at Callao Cave, Luzon, Philippines. Journal of Human Evolution 59:123-132.

Mijares, A. S. B. 2006. The early Austronesian migration to Luzon: perspectives from the Peñablanca cave sites. Bulletin of the IndoPacific Prehistory Association 26:72-78.

Mona, S., K. E. Grunz, S. Brauer, B. Pakendorf, L. Castrì, H. Sudoyo, S. Marzuki, et al. 2009. Genetic admixture history of eastern Indonesia as revealed by Y-chromosome and mitochondrial DNA analysis. Molecular Biology and Evolution 26:1865-1877.

Mona, S., M. Tomasetto-Ponzetta, S. Brauer, H. Sudoyo, S. Marzuki, and M. Kayser. 2007. Patterns of Y-chromosome diversity intersect with the trans-New Guinea hypothesis. Molecular Biology and Evolution 24:2546-2555.

Moodley, Y., B. Linz, Y. Yamaoka, H. M. Windsor, S. Breurec, J.-Y. $\mathrm{Wu}, \mathrm{A}$. Maady, et al. 2009. The peopling of the Pacific from a bacterial perspective. Science 323:527-530.

Ogawa, H. 2005. Typological chronology of pottery assemblages from the Lal-Lo shell midden in northern Luzon, Philippines. Journal of Southeast Asian Archaeology 25:1-30.

Oppenheimer, S., and M. Richards. 2002. Polynesians: devolved Taiwanese rice farmers or Wallacean maritime traders with fishing, foraging and horticultural skills. In Examining the farming/language dispersal hypothesis. P. Bellwood and C. Renfrew, eds. Pp. 287-298. Cambridge: McDonald Institute for Archaeological Research.

Ostler, N. 2005. Empires of the word. London: Harper Perennial.

Pawley, A. 1999. Chasing rainbows: implications of the rapid dispersal of Austronesian languages for subgrouping and reconstruction. In Selected papers from the Eighth International Conference on Austronesian Linguistics. E. Zeitoun and P. J.-K. Li, eds. Pp. 95-138. Taipei: Institute of Linguistics, Academia Sinica.

- 2002. The Austronesian dispersal: languages, technologies 
and people. In Examining the farming/language dispersal hypothesis. P. Bellwood and C. Renfrew, eds. Pp. 251-273. Cambridge: MacDonald Institute for Archaeological Research.

2007. Recent research on the historical relationships of thi Papuan languages. In Genes, language and culture history in the Southwest Pacific. J. Friedlaender, ed. Pp. 36-60. Oxford: Oxford University Press.

Paz, V. 2002. Island Southeast Asia: spread or friction zone? In Examining the farming/language dispersal hypothesis. P. Bellwood and C. Renfrew, eds. Pp. 275-285. Cambridge: McDonald Institute for Archaeological Research.

Pearsall, D. 2003. Plant food resources of the Ecuadorian Formative: an overview and comparison to the central Andes. In Archaeology of Formative Ecuador. J. S. Raymond, R. L. Burger, and J. Quilter eds. Pp. 213-258. Washington, DC: Dumbarton Oaks.

Piper, P., H.-C. Hung, F. Z. Campos, P. Bellwood, and R. Santiago. 2009. A 4000 year old introduction of domestic pigs into the Philippine Archipelago. Antiquity 83:687-695.

Renfrew, C. 2002. "The emerging synthesis": the archaeogenetics of language/farming dispersals and other spread zones. In Examining the farming/language dispersal hypothesis. P. Bellwood and C. Renfrew, eds. Pp. 3-16. Cambridge: McDonald Institute for Archaeological Research.

Rispoli, F. 2008. The incised and impressed pottery of mainland Southeast Asia: following the paths of Neolithization. East and West 57:235-304.

Ross, M. 2008. The integrity of the Austronesian language family from Taiwan to Oceania. In Past human migrations in East Asia: matching archaeology, linguistics and genetics. A. Sanchez-Mazas, R. Blench, M. D. Ross, I. Peiros, and M. Lin, eds. Pp. 161-181. London: Routledge.

Ross, M., A. Pawley, and M. Osmond. 2007. The lexicon of protoOceanic: the culture and environment of ancestral Oceanic society. 2nd edition. Canberra: Australian National University E Press.

Sand, C. 1999. Archéologie des origines: le lapita calédonien. Nouméa, New Caledonia: Departement Archéologie, Service des musées et du patrimoine de Nouvelle-Calédonie.

Simanjuntak, T., M. J. Morwood, F. S. Intan, I. Mahmud, K. Grant, N. Somba, B. Akw, and D. Utomo. 2008. Minanga Sipakko and the Neolithic of the Karama River. In Austronesian in Sulawesi. T. Simanjuntak, ed. Pp. 57-76. Depok, Indonesia: Center for Prehistoric and Austronesian Studies.

Smith, B. D. 2001. Low-level food production. Journal of Archaeological Research 9:1-43.

2011. The cultural context of plant domestication in eastern North America. Current Anthropology 52(suppl. 4):S471-S484.

Snow, B., R. Shutler, D. Nelson, J. Vogel, and J. Southon. 1986. Evidence of early rice cultivation in the Philippines. Philippine Quarterly of Culture and Society 14:3-11.

Summerhayes, G., and A. Anderson. 2009. An Austronesian presence in southern Japan: early occupation in the Yaeyama Islands. Bulletin of the Indo-Pacific Prehistory Association 29:76-91.

Tabbada, K. A., J. Trejaut, J.-H. Loo, Y.-M. Chen, M. Lin, M. MirazónLahr, T. Kivisild, and M. C. A. De Ungria. 2010. Philippine mitochondrial DNA diversity: a populated viaduct between Taiwan and Indonesia? Molecular Biology and Evolution 27:21-31.

$\rightarrow$ Terrell, J. 2010. Social network analysis of the genetic structure of Pacific Islanders. Annals of Human Genetics 74:211-232.

Tsang, C.-H. 2005. Recent discoveries at a Tapenkeng culture site in Taiwan: implications for the problem of Austronesian origins. In The peopling of East Asia. L. Sagart, R. Blench, and A. SanchezMazas, eds. Pp. 63-73. London: RoutledgeCurzon.

Tsang, C.-H., K.-T. Li, and C.-Y. Chu. 2006. Footprints of ancestors: archaeological discoveries in Tainan Science-Based Industrial Park. Tainan: Tainan County Government. [In Chinese.]

Valentine, B., G. Kamenov, and J. Krigbaum. 2008. Reconstructing Neolithic groups in Sarawak, Malaysia through lead and strontium isotope analysis. Journal of Archaeological Science 35:1463-1473.

Yuan, J., R. Flad, and L. Yunbing. 2008. Meat acquisition patterns in the Neolithic Yangzi River valley, China. Antiquity 82:351-366.

Zhang, C., and H.-C. Hung. 2008. The Neolithic of southern China: origin, development and dispersal. Asian Perspectives 47:299-329.

. 2010. The emergence of agriculture in southern China. Antiquity 84:11-25.

Zhao, Z. 2011. New archaeobotanic data for the study of the origins of agriculture in China. Current Anthropology 52(suppl. 4):S295S306. 